\title{
REPRESENTASI SEMANGAT BERBAGI EKOFEMINISME MELALUI BATIK TULIS
}

\author{
Argyo Demartoto \\ Universitas Sebelas Maret \\ argyodemartoto_fisip@staff.uns.ac.id
}

\section{ABSTRAK}

Tujuan penelitian ini adalah mengeksplorasi upaya yang dilakukan perempuan pembuat batik tulis dengan pewarna alami sebagai wujud peduli lingkungan. Penelitian kualitatif dengan metode eksploratif ini dilakukan di kampung batik Laweyan dan Kauman Surakarta. Hasil penelitian menunjukkan bahwa kemunculan batik cap dan printing menyebabkan keberlangsungan batik tulis terpinggirkan. Pengusaha batik banyak yang beralih dan hanya sedikit yang bertahan dengan produksi batik tulis. Kesempatan untuk bekerja dan menyalurkan keterampilan bagi buruh pembatik perempuan berkurang. Produksi batik cap dan printing yang menggunakan pewarna buatan, berdampak buruk pada lingkungan dengan potensi limbahnya adalah bentuk ketidakadilan karena mencemari lingkungan dan meminggirkan perempuan. Representasi semangat berbagi ekofeminisme melalui kreasi batik tulis dengan pewarna alami sebagai upaya perempuan untuk bekerja dan berperan dalam menjaga kelestarian lingkungan. Gerakan social ini wujud kepedulian perempuan terhadap kelangsungan lingkungan hidup, menyampaikan nilai pengendalian diri dan nafsu menguasai di tengah industrialisasi, serta wujud nyata pembangunan berkelanjutan dan bisnis beretika.

Kata kunci: Batik tulis, pewarna alami, gerakan sosial, ekofeminisme, lingkungan hidup. 
Representasi Semangat Berbagi Ekofeminisme ...

\section{ABSTRACT}

The objective of research was to explore the attempt the women producing batik tulis using natural colorant as the manifestation of environment care. This study was a qualitative research using explorative method taken place in Kampung Batik Laweyan and Kauman, Surakarta. The result of research showed that the emergence of stamping and printing batik led the batik tulis (written batik) to be marginalized. Many batik entrepreneurs shifted to them and only few survived with batik tulis production. The opportunity of working and applying the female batik laborers' skill reduced. The production of stamping and printing batik using artificial colorant affected adversely the environment with its waste as the form of injustice as it contaminated the environment and marginalized the women. The spirit of ecofeminism sharing through batik tulis creation with natural colorant was the women's attempt of working and contributing to conserve the environment. This social movement is the manifestation of women's care about the living environment sustainability, conveying self-controlling values and controlling the passion of dominating amid industrialization, and the manifestation of sustainable development and ethical business.

Keywords: batik tulis, natural colorant, social movement, ecofeminism, living environment

\section{A. Pendahuluan}

Batik Indonesia sudah tidak diragukan lagi kepopulerannya, bahkan menjadi pakaian nasional serta identitas Indonesia. Batik telah dikenal dan populer di seluruh dunia. Beberapa desainer kelas dunia yang menggunakan batik sebagai bahan karyanya termasuk artis dunia mengenakan batik sebagai busananya (Tirta, 1996:1). Sejak 2009, UNESCO mengakui secara resmi batik sebagai warisan kemanusiaan untuk budaya lisan dan nonbendawi. Menurut Soedarmono (2006), Asikin (2008) dan Nurainun et al, (2008) bahwa batik adalah istilah yang digunakan untuk menyebut kain bermotif yang dibuat dengan teknik resist menggunakan material lilin malam. Dari segi bahasa, batik berasal dari bahasa Jawa, yaitu amba dan nitik yang berarti menuliskan atau menorehkan titik-titik. Jadi, batik merupakan kain bergambar yang dibuat secara khusus dengan cara menuliskan malam pada kain dan pengolahannya diproses dengan cara tertentu. Van Roojen (2001) menyatakan bahwa sejak lama batik menjadi salah satu kekayaan tekstil dan budaya di Indonesia. Kain panjang batik dan 
sarung hingga kini masih digunakan oleh wanita maupun pria terutama di pedesaan dan telah berabad-abad lamanya menjadi bagian penting dalam khazanah busana Melayu. Batik tidak hanya sekedar kain sederhana yang digunakan wanita dan pria Jawa sebagai bawahan atau pakaian kala upacara adat saja, tetapi telah menjadi pakaian sehari-hari bagi seluruh kalangan status sosial dan usia. Sesuai dengan perkembangan jaman batik juga mulai berkembang jenisnya, yang awalnya hanya berupa batik tulis, sekarang sudah terdapat banyak batik, antara lain batik cap dan printing (Doellah, 2002:20; Wijaya, 2011:35).

Menurut van Roojen (2001) dan Wijaya (2009),batik tulis merupakan jenis batik yang tertua dibanding dengan lainnya. Dari segi proses pembuatannya memakan waktu yang lebih panjang. Satu helai kain batik tulis tradisional yang dikerjakan dengan canting setidaknya memerlukan waktu kurang lebih 2 minggu. Sedangkan batik cap dengan teknologi cap, hanya dalam waktu 2 hari saja sudah dapat menghasilkan puluhan helai kain, bahkan dengan teknologi terbaru printing dalam waktu 1 hari dapat menghasilkan ratusan helai kain batik printing. Dengan demikian dapat dinyatakan bahwa batik tulis memiliki nilai jual yang lebih tinggi dibanding dengan batik cap dan batik printing. Kehadiran batik cap dan printing menggeser keberadaan batik tulis yang merupakan asal kelahiran batik, sehingga kondisi dan keberlangsungan batik tulis kian terpuruk. Dengan keterbatasannya batik tulis mulai kalah bersaing dengan batik cap dan printing yang relatif dijual dengan harga murah dan diproduksi massal. Oleh karena itu pengusaha batik banyak yang beralih memproduksi batik cap dan printing hingga menyisakan sedikit pengusaha yang bertahan dengan produksi batik tulis. Eksistensi batik tulis yang kalah bersaing dengan batik cap dan printing tidak hanya berdampak buruk bagi pengusaha, namun buruh pembatik yang umumnya perempuan juga terkena dampaknya, karena membatik (tulis) sudah menjadi profesi yang turun-temurun dilakukan. Dominasi produksi dan pasar oleh batik cap dan printing turut mengurangi kesempatan perempuan untuk bekerja dan menyalurkan keterampilannya. Batik tulis identik dengan perempuan karena memerlukan proses membatik layaknya melukis langsung di kain yang sudah berpola sehingga diperlukan kesabaran dan ketelitian. Sedangkan batik cap dan printing yang menggunakan alat cap dan printing dalam proses membatiknya relatif tidak membutuhkan keterampilan melukis layaknya perempuan saat membatik tulis (Hunga, 2004:22).

Menurut Kementerian Perindustrian Republik Indonesia Tahun 2014, bahwa selama kurun empat tahun terakhir Indonesia berhasil meningkatkan 
Representasi Semangat Berbagi Ekofeminisme ...

ekspor batik dari USD32 juta pada 2008 menjadi USD 278 juta pada 2012. Pada kuartal I/2013 ekspor batik Indonesia mengalami pertumbuhan sebesar 18,49\% dibandingkan dengan periode yang sama pada tahun sebelumnya. The GermanIndonesian Chamber of Industry and Commerce-EKONID (2011) berpendapat bahwa produksi massal batik cap dan printing menunjukkan kenyataan yakni dominasi kapitalisme dalam industri batik yang cenderung memusatkan pada keuntungan semata dan cenderung mengabaikan kelestarian lingkungan. Batik cap dan printing yang sifatnya massal dan efisien membawa konsekuensi penggunaan pewarna buatan/kimia. Penggunaan pewarna buatan memberikan dampak buruk bagi lingkungan dengan potensi limbahnya. Limbah tersebut tentu saja menjadi penyebab pencemaran lingkungan sekitar yang akan mengancam kelestarian alam dan keberlangsungan makhluk hidup yang mendiaminya.

Dalam kegiatan workshop dan pameran zat pewarna alami untuk mendukung program pemberdayaan usaha mikro kecil menengah ramah lingkungan di Universitas Gadjah Mada, 2012 dinyatakan bahwa limbah yang berasal dari proses pewarnaan batik yang masih menggunakan pewarna sintesis naptol, remasol, indigosol, dan sejenisnya. Bahan pewarna kimia pada batik tersebut tergolong tidak ramah lingkungan. Apabila limbah-limbah mengalir ke dalam tanah, bahan-bahan tersebut tentu merusak ekosistem tanah. Pasalnya, bakteri tanah tidak mampu mendegradasi bahan-bahan kimia. Bahan-bahan yang bersifat karsinogenik pun jika masuk ke dalam tubuh bisa membahayakan kesehatan manusia. Disamping berbahaya bagi manusia, bahan pewarna naptol dan indigisol bisa mengakibatkan organisme dalam air akan mati. Hal itu disebabkan bahan pewarna tersebut dapat mengubah nilai Biochemical Oxygen Demand (BOD) dan Chemical Oxygen Demand (COD) dalam air. Kandungan oksigen $\left(\mathrm{O}_{2}\right)$ yang notabene diperlukan organisme air akan menurun jika limbah pewarna masuk ke air.

Pembangunan ekonomi harus mengedepankan upaya pelestarian lingkungan hidup sesuai dengan Sustainable Development Goals (SDG's), namun kenyataan yang terjadi justru bertolak belakang (Griggs et al, 2014). Kasus limbah batik karena pewarna buatan menjadi salah satu contohnya. Dalam cengkeraman kapitalisme, relasi dengan alam tidak berlangsung dalam suasana kesatuan, keharmonisan, keselarasan dan keseimbangan, tetapi beranjak kepada hubungan yang hierarkis dengan manusia kapitalis sebagai dominatornya (Mokonginta, 2009). Di tengah massif dan massalnya produksi batik cap dan printing demi kebutuhan pasar, masih ada pengusaha yang memproduksi batik tulis dan bahkan menggunakan pewarna alami. Mereka tidak terlalu mengamini 
pasar dan justru melakukan hal yang berbeda. Upaya tersebut tidak sekedar mengakumulasi keuntungan semata namun menjadi wujud kepedulian terhadap keberlangsungan lingkungan hidup. Wujud kepedulian tersebut merupakan suatu gerakan sosial (Nurainun et al, 2008; Pringgenis et al, 2014).

Gerakan sosial adalah terminologi untuk sejumlah fenomena sosial dan politik seperti revolusi, sekte-sekte keagamaan, organisasi-organisasi politik, atau satu isu yang mengkampanyekan banyak hal (Oberschall, 1993; Meyer dan Whittier, 1994; Henslin, 2006; Hutagalung et al., 2006). Menurut Singh (2001) dan Lofland (2007) ada beberapa perspektif untuk melihat gerakan sosial baru, seperti perspektif perilaku kolektif, teori mobilisasi sumber, proses politik, dan gerakan-gerakan sosial baru. Perspektif yang sesuai dengan konteks ini. Gerakan sosial baru merupakan tipe gerakan sosial yang memiliki tampilan karakter yang baru atau unik dimana gerakan ini lebih berpusat pada tujuan-tujuan non material dan menekankan pada perubahan-perubahan dalam gaya hidup atau kebudayaan daripada mendorong perubahan spesifik pada kebijakan publik atau perubahan ekonomi (Nash $E d, 2005)$. Perkembangan gerakan sosial, ekologi dan feminisme menemukan titik temu dan proses integrasi melalui ekofeminisme.

Ekofeminisme merupakan istilah yang dikenal banyak orang akibat terpublikasinya gerakan Chipko di India pada kurun waktu sekitar 1970 ketika para wanita setempat berdemonstrasi mempertahankan hutan dari pengambilan kayu secara komersial yang diprakarsai pemerintah India (Warren, 1993; Mitchel, 1997; Arivia, 2002; Mitchel et al, 2003; Shiva dan Mies, 2005; Tong, 2013). Gerakan feminisme dan ekologis mempunyai tujuan yang saling memperkuat, yakni hendak membangun pandangan terhadap dunia prakteknya yang tidak berdasarkan model-model yang patriarkhis dan dominasi-dominasi. Ekofeminisme memiliki misi atau tujuan yang strategis terkait penghapusan dominasi atau penindasan bagi perempuan dan alam. Ekofeminisme memiliki kelebihan yaitu mampu menerangkan latar belakang subordinasi perempuan serta kerusakan lingkungan hidup global. Artinya, ekofeminisme hadir dengan perspektif baru yang integratif serta ramah terhadap perempuan dan alam (Isshiki, 2000; Harper, 2004; Wulan,2007).

Menurut Schaper (2002), D'Souza dan Peretiatko (2002), Diekman dan Preisendorf (2003), Ramjeawon (2004) dan Siswoyo (2006) terdapat keterkaitan antara industri kecil dan lingkungan. Sedangkan menurut Demartoto (2012) dan Hunga (2013) terdapat keterkaitan perempuan dengan industri kecil. Beberapa penelitian mengkaji gerakan sosial terhadap kelestarian lingkungan hidup 
(Sridhar,2010; Sianipar et al, 2013; Samorna, 2013; Meliyana et al, 2014; Lailia,2014). Akan tetapi jarang yang mengkaji perempuan sebagai aktor utamanya. Penelitian ini menganalisis upaya atau gerakan sosial kepedulian terhadap lingkungan yang dilakukan perempuan pembuat batik tulis dengan pewarna alami.

Penelitian kualitatif ini menggunakan metode eksploratif. Peneliti mengeksplorasi entitas perempuan yang berkarya melalui batik tulis dengan pewarna alami di kampung batik Laweyan dan Kauman di Surakarta secara detail dengan melibatkan data yang mendalam berupa informasi multi sumber yang dilakukan Juli - September 2016 (Creswell, 2006). Teknik pengambilan sampel yang digunakan adalah maximum variation sampling, artinya informan dipilih karena memenuhi kriteria atau tujuan tertentu dari peneliti berdasarkan konsep teoritis yang digunakan, keingintahuan pribadi peneliti, karakteristik empiris dan lain-lain (Daymon dan Holloway, 2011). Sumber data utama penelitian ini adalah perempuan baik pengusaha batik maupun buruh batik yang terlibat pada proses gerakan sosial baru dari Paguyuban Kampung Wisata Batik Kauman dan Forum Pengembangan Kampung Batik Laweyan Surakarta (Denzin,1970). Teknik pengumpulan data dilakukan dengan observasi, wawancara mendalam, dan dokumentasi. Untuk validitas dan reliabilitas data peneliti menggunakan triangulasi sumber data (Bryman, 2011). Dalam penelitian ini digunakan model analisis interaktif yang terdiri dari pengumpulan data, reduksi data, penyajian data dan penarikan kesimpulan (Miles et al, 2014).

\section{B. Pembahasan}

Kota Surakarta sebagai Kota Budaya menyuguhkan batik sebagai salah satu ikon terkenal di Indonesia. Tidak jarang banyak wisatawan yang menjadikan Kota Surakarta sebagai kota tujuan wisata di Indonesia. Banyak kegiatan wisata yang menarik yang menggunakan batik sebagai tema, seperti pawai karnaval hingga acara-acara adat yang harus menggunakan batik sebagai busana resmi. Kota Surakarta dikenal sebagai kota produsen batik terbesar di Indonesia dengan kampung batik Laweyan dan Kauman yang dijadikan ikon tempat pembuatan batik serta tempat penjualan batik. Kedua kampung batik tersebut sudah sangat terkenal sebagai tempat penghasil batik terbesar di Kota Surakarta sejak jaman penjajahan, selain Pasar Klewer, pusat-pusat perbelanjaan dan butik-butik yang mendukung keberadaan batik.Batik sebagai ikon Kota Surakarta tentu berdampak pada perekonomian masyarakat. Banyak penduduk yang bekerja 
disentra produksi batik terutama perempuan baik sebagai pengusaha batik serta tenaga kerja atau buruh.

Akan tetapi saat ini dalam industri batik, telah terjadi peminggiran perempuan karena banyak pengusaha batik yang beralih dari memproduksi batik tulis ke batik cap dan printing. Geliat industri batik memang agak meredup, ini dapat dilihat dari berkurangnya usaha-usaha produksi batik dan mengalihkan ke usaha yang lain. Jenis industri batik di Surakarta termasuk ke dalam kategori jenis usaha menengah dan sedang. Berdasarkan jumlah pekerja pada masing-masing perusahaan batik, di Kecamatan Laweyan. Surakarta terdapat kurang lebih 72 perusahaan batik. Jumlah pekerja pada sektor industri batik di kawasan Kota Surakarta kurang lebih 7000 orang berdasarkan data tahun 2006 (Nurainun et al, 2008).

\section{Peran Prempuan dalam Proses Pembuatan Batik Tulis}

Dalam ekonomi pasar posisi batik tulis telah banyak tergeser oleh batik cap dan printing yang biaya produksinya lebih hemat sehingga harga jualnya relatif lebih murah.Kenyataan ini tidak berarti batik tulis sudah mati. Menurut seorang perempuan pengusaha batik (A1) bahwa di Laweyan batik tulis masih memiliki pasar yang meski kecil namun tidak dapat tergantikan terutama penggunaannya dalam berbagai acara adat Jawa. Batik tulis memiliki kelebihan dan ciri khas tersendiri yang bahkan tidak akan dapat dimiliki oleh batik cap dan printing.

Peran perempuan dalam batik tulis menurut beberapa pekerja batik perempuan (B1,B2 dan B3) berawal dari posisi batik tulis tidak saja salah satu bentuk kekayaan produk tekstil Indonesia, namun juga menjadi salah satu bentuk hasil kerajinan tangan. Sebagai bentuk kerajinan tangan membawa konsekuensi yakni memakan waktu yang panjang dalam proses pembuatannya atau dapat dikatakan cukup rumit. Alat-alat yang digunakan dalam proses pembuatan batik tulis adalah alat tradisional seperti canting. Proses pembuatan batik tulis meliputi beberapa tahapan seperti mola (membuat pola), ngiseni (mengisi bagian yang sudah dibuat polanya), nerusi (membatik pada sisi sebaliknya), nemboki (menutup bagian kain yang tidak akan diwarnai), mbiriki (proses penghalusan tembokan), pewarnaan, nglorot (merebus kain agar malamnya larut / lepas) dan mbabari (van Roojen, 2001; Doellah, 2002).

Proses pembuatan batik tulis yang tergolong rumit dan bertahap. Batik tulis memiliki nilai tertentu yang sebenarnya telah mempertimbangkan kepentingan keberlanjutan lingkungan ketimbang jenis batik lainnya yakni menghargai tiap proses sehingga di dapat hasil batik yang indah dan orisinil 
meski secara jumlah produksi sangat terbatas. Keterbatasan jumlah produksi inilah yang sebenarnya menjelma menjadi kekuatan dan cara menjaga kelestarian lingkungan. Keterbatasan tersebut berarti menjadi batasan agar produksi batik tulis yang menghasilkan limbah dapat terkendali sehingga tidak sampai mencemari lingkungan. Hal ini dikemukakan oleh salah seorang peneliti gender dan lingkungan yakni C dari Pusat Penelitian dan Pengembangan Gender Lembaga Penelitian dan Pengabdian kepada Masyarakat (P3G LPPM) Universitas Sebelas Maret.

Salah seorang perempuan pengusaha batik di kampung Laweyan (A2) berpendapat bahwa dalam proses pembuatan batik tulis memang mengharuskan adanya ketelitian dan ketelatenan, terlebih saat proses mengisi pola dengan lilin dalam canting. Proses tersebut dapat dikatakan sebagai proses yang sangat krusial karena harus sesuai dan mengikuti pola gambar yang rumit. Menariknya, para perempuanlah yang selalu mengerjakan proses tersebut. Hal ini menunjukkan bahwa memang ketelatenan, ketelitian dan bahkan kesabaran yang dimiliki perempuan menjadi kekuatan dan daya cipta di balik produk batik tulis. Dengan demikian, dapat dikatakan bahwa perempuan menjadi kreator dalam batik tulis.

Sayangnya, kondisi pasar makin menggeser eksistensi batik tulis dan berdampak pada perempuan. Kondisi tersebut menggeser tenaga kerja perempuan yang saat batik tulis masih berjaya menjadi tenaga kerja terbesar menjadi berbalik mengalami penurunan yang cukup besar karena berkembangnya batik cap dan printing. Hal ini disebabkan karakteristik yang berbeda antara batik tulis dengan batik cap dan printing. Proses pembuatan batik dengan sistem cap telah melahirkan perubahan dalam karakter industri batik yang paralel dengan perkembangan sifat produksi dari sistem kerajinan menjadi pertukangan (Soedarmono, 2006). Oleh karena itu, pada masa kejayaan batik cap dan printing saat ini tenaga kerja perempuan mulai tergusur dan tergantikan oleh tenaga kerja laki-laki yang cocok dengan sistem pertukangan dalam produksi batik cap dan printing.

Keberadaan industri batik cap dan printing menyebabkan dampak buruk bagi alam atau lingkungan dan perempuan. Bagi lingkungan berarti ancaman besar bagi pencemaran lingkungan, karena besarnya produksi yang menggunakan pewarna buatan yang berasal dari bahan kimia menjadi ancaman berbahaya. Selain itu, tidak jarang para pengusaha tidak mengelola limbahnya dengan benar atau tidak memiliki Instalasi Pengolahan Air Limbah (IPAL) yang memadai. Sedangkan kerugian bagi perempuan adalah berkurang atau 
sempitnya kesempatan perempuan untuk bekerja di industri batik. Hal ini berarti kemajuan indutri batik cap dan printing mengurangi ruang kreasi dan ekspresi perempuan.

\section{Makna Semangat Berbagi Ekofeminisme Untuk Mengendalikan Sumber Daya}

Batik tulis yang notabene merupakan kerajinan tangan dianggap lamban dan tidak sesuai dengan semangat kapitalis yang sudah merasuk dalam sistem pasar saat ini. Proses produksi batik cap dan printing yang lebih sesuai dengan semangat kapitalis juga tidak terlalu membutuhkan perempuan sebagai tenaga kerja utamanya. Perempuan dan batik tulis pada akhirnya sama-sama terpinggirkan. Kondisi memprihatinkan yang dialami oleh alam dan perempuan merupakan ketidakadilan menurut pandangan ekofeminisme. Ekofeminisme mengusung semangat berbagi layak dikembangkan secara luas. Semangat berbagi ini menjadi dasar untuk bertahan hidup dan membangun segalanya, serta diperlukan hubungan cinta kasih dan keadilan, yang kesemuanya dipanggil untuk membangun kebudayaan dengan gaya hidup yang eco-friendly serta women-friendly (Buckingham, 2004). Semangat berbagi memiliki arti penting yakni mengendalikan diri dalam mempergunakan sumber daya yang ada dan memberikan kesempatan yang sama dalam mempergunakannya. Manfaat penerapan semangat berbagi sangat penting terutama diberikan pada perempuan dan alam yang sama-sama berada pada kondisi terpinggirkan. Semangat berbagi layaknya ditunjukkan dengan pemberian kesempatan dan ruang yang cukup bagi perempuan berkarya dan berkreasi serta berperan melestarikan alam. Hal tersebut bukanlah sesuatu yang utopis namun justru realistis dan dapat diwujudkan dengan adanya kreasi batik tulis dengan pewarna alami.

\section{Batik Tulis Sebagai Gerakan Fasis Lingkungan}

Kondisi lingkungan yang mulai terancam oleh produksi massal batik cap dan printing dengan pewarna buatan atau sintetis ternyata mengundang empati berbagai pihak terutama kaum perempuan baik itu perempuan pengusaha maupun tenaga kerja atau buruh pembuat batik tulis. Empati tersebut ditunjukkan dengan memproduksi dan membuat kreasi batik tulis dengan pewarna alami. Salah seorang yang melakukannya adalah A3, pemilik industri batik tulis X di Kauman Surakarta. Kesadaran untuk menggunakan pewarna batik alami telah dilakukan sejak memulai usaha tahun 1992. Penggunaan 
pewarna alami dilakukan karena A3 tidak ingin mencemari lingkungan tempat usahanya dengan limbah beracun dan berbahaya serta di Kota Surakarta tempat tinggalnya juga banyak terdapat tanaman atau bahan yang bisa digunakan untuk mewarnai dan membuat motif batiknya.

Produk batik tulis $\mathrm{X}$ merupakan batik ramah lingkungan karena hanya menggunakan pewarna alami. Bahan-bahan seperti kunyit dan sekam merupakan bahan yang digunakan untuk menghasilkan pewarna alami batik tulis X. Menurut A3, proses pewarnaan dengan pewarna alami juga cukup sederhana yaitu melalui pewarnaan dengan sekam. Prosedur pewarnaan sebagai berikut:

Langkah pertama adalah menyediakan abu sekam sebanyak 2 karung ukuran $40 \mathrm{~kg}$. Abu sekam tersebut kemudian diayak dan hasil ayakan itu dimasukkan ke dalam ember berisi air sebanyak 20 liter. Kain yang ingin diwarnai lalu dimasukkan ke dalam ember berisi campuran abu sekam dan air itu. Celupkan dan angkat kain itu dari ember. Lakukan hal ini berulangulang hingga warna kain berubah mengikuti warna campuran air di ember. Setelah itu, rendam kain tersebut di dalam ember yang masih berisi campuran air dan sekam selama tiga hari. Setelah itu, langkah selanjutnya adalah melakukan fiksasi terhadap kain yang telah direndam dalam air sekam tersebut menggunakan tawas.

Selain batik tulis $X$ di Surakarta, juga terdapat beberapa kampung yang telah mengembangkan dan memproduksi batik tulis dengan pewarna alami seperti di Laweyan dan Kauman Surakarta. Berbagai bahan alam banyak digunakan sebagai penghasil warna alami yang siap diaplikasikan pada batik. Untuk batik Laweyan Surakarta yang identik dengan warna cokelat menggunakan kulit buah jolawe (Hartini et al, 2014). Batik tulis di Laweyan menggunakan bahan seperti daun dan batang nila untuk menghasilkan warna biru, kulit batang tingi untuk warna cokelat, buah jolawe, bunga srigading dan kayu tegaran untuk warna kuning, kayu batang mahoni dan sabut kelapa untuk warna cokelat, biji buah kesumba untuk warna orange, daun dan kulit batang mangga untuk warna hijau (Widodo et al, 2012). Sementara itu, batik di RT dan RW lain di Laweyan menggunakan indigo yang menghasilkan warna hijau dan biru, daun dan batang tanaman mangrove yang menghasilkan warna coklat muda hingga coklat tua gelap (Pringgenies et al, 2013).

Berbagai kreasi batik tulis dengan pewarna alami dibuat oleh tangantangan perempuan tidak saja merupakan upaya perempuan untuk bekerja atau berkreasi, melainkan menunjukkan peran perempuan dalam menjaga kelestarian lingkungan. Peran inilah yang disebut sebagai suatu gerakan sosial, karena membawa isu atau mengkampanyekan perubahan dalam penggunaan 
pewarna alami dalam produksi batik. Hal ini sejalan dengan pernyataan Plummer (2010) dan Meliyana et al (2013), bahwa peran perempuan yang turut berpartisipasi dalam menjaga kelangsungan lingkungan merupakan salah satu bentuk gerakan sosial baru. Gerakan sosial baru merupakan gerakan yang lebih menyuarakan, mengarahkan dan berjuang dengan kondisi mendasar keberadaan manusia serta mungkin keberadaan yang layak dimasa depan, termasuk berorientasi kepada keselamatan bumi, mendukung pelestarian alam dimana manusia merupakan bagian darinya.

Kegiatan para perempuan baik sebagai pengusaha batik dan tenaga kerja pembatik yang menggunakan pewarna alami karena kesadaran akan bahaya pencemaran lingkungan merupakan suatu gerakan sosial baru terkait dengan isu lingkungan hidup. Kerja dan kegiatan yang dilakukan oleh para perempuan tersebut tergolong sebagai gerakan sosial baru yang berfokus pada gerakan lingkungan dengan kategori ecofacism (fasis lingkungan) dimana kelompok ini lebih memperjuangkan lingkungan berdasarkan kesadaran atas pentingnya menjaga lingkungan itu sendiri. Kelestarian lingkungan menurut pandangan ecofacism berarti salah satu isu strategis yang diperhatikan oleh semua orang. Upaya ini dilakukan oleh masyarakat mulanya untuk kebersihan kampung yang kemudian berkembang untuk keberlanjutan kampung dengan ikut andil dalam melestarikan lingkungan hidup di ranah rumah tangga. Upaya-upaya tersebut diantaranya dilakukan dengan mendaur ulang sampah, penghematan air dan sosialisasi kepada masyarakat lain akan pentingnya menjaga keberlanjutan lingkungan (Lailia, 2014). Dalam konteks ini, upaya yang dilakukan oleh perempuan untuk menjaga kelestarian lingkungan sekitar mereka yang notabene tempat produksi batik dengan cara mengurangi ancaman pencemaran limbah yakni menggunakan pewarna alami yang ramah lingkungan.

Pada awalnya gerakan perempuan yang turut menjaga kelangsungan lingkungan hidup yakni membuat batik tulis dengan pewarna alami merupakan gerakan kategori eco facism yang sebenarnya hanya akan berdampak terbatas pada lingkungan sekitar mereka saja. Namun, tanpa disadari melalui produk yang dihasilkannya justru dampak gerakan tersebut dapat melampaui batasannya, atau lebih luas dan bahkan mampu menyentuh orang-orang lain di luar lingkungan mereka. Produk batik yang dihasilkan tersebut mampu menembus pasar lokal, regional, nasional dan bahkan ekspor. Meskipun sebenarnya jika ditilik dari harga jualnya memang tergolong jauh lebih tinggi jika dibanding dengan batik cap atau printing. 
Rata-rata harga jual batik tulis dengan pewarna alami di pasar dalam negeri dengan harga minimal Rp 500 ribu hingga di atas Rp 1 juta, sementara batik dengan pewarna buatan/sintetis dijual dengan harga minimal di bawah $\mathrm{Rp} 100$ ribu. Harga jual batik tulis dengan pewarna alami memang tinggi, namun produk batik tersebut memiliki keunggulan yang tidak dimiliki produk batik lainnya, seperti warna yang dihasilkan lebih indah dan khas, warna lebih tahan lama atau tidak cepat memudar dan cocok dipakai oleh orang yang memiliki kulit sensitif terhadap bahan kimia. Berbagai keunggulan inilah yang membuat pasar batik tulis pewarna alami masih begitu terbuka meski dalam dominasi batik cap dan printing yang umumnya memakai pewarna buatan atau sintetis.

Keunggulan batik tulis pewarna alami tidak saja terbatas dari segi fisik produk. Lebih dari itu, batik tersebut juga mampu membawa dan menyampaikan pesan mengenai pentingnya menjaga kelangsungan lingkungan hidup. Terlebih jika produk batik tersebut mampu menembus pasar ekspor atau rutin diikutsertakan dalam acara expo atau pameran produk dan acara peragaan busana baik taraf regional, nasional maupun internasional. Produk batik tulis alami yang tercipta dari tangan para perempuan dari kampung Laweyan dan Kauman Surakarta, secara tidak langsung mampu menyampaikan pesan atau mengkampanyekan tentang pentingnya memiliki kepedulian terhadap kelangsungan lingkungan hidup. Selain itu, produk batik tersebut sebenarnya juga bermaksud mendorong perubahan gaya hidup yakni tetap memperhitungkan lingkungan hidup dalam aktivitas apapun termasuk dalam pemilihan pakaian sekalipun.

Gerakan sosial perempuan yang berkreasi menghasilkan batik tulis warna alami mampu menghadirkan kesadaran orang lain, termasuk pembeli dan orang-orang lain yang mengetahui produk tersebut akan kepedulian terhadap lingkungan. Selain itu, gerakan perempuan tersebut mampu menyampaikan nilai penting yang selama ini banyak diabaikan dan dilupakan banyak orang, terlebih saat memanfaatkan sumber daya di bumi, yakni soal pengendalian diri. Pengendalian diri yang dimaksud adalah tidak memelihara sifat serakah dengan mengeksploitasi berlebih tanpa memikirkan kepentingan generasi selanjutnya. Tanpa disadari sifat serakah hanya akan mendorong pemenuhan nafsu untuk menguasai terutama di tengah masa industrialisasi. Banyak orang akan berlomba-lomba dalam akumulasi keuntungan dan tidak segan untuk mengeksploitasi seluruh sumber daya yang ada di bumi tanpa peduli limbah yang dihasilkan sehingga ancaman bencana ekologi pun makin tidak bisa dihindari. 
Gerakan sosial yang dilakukan perempuan di kampung Laweyan dan Kauman Surakarta memberikan contoh nyata penerapan pembangunan yang berkelanjutan. Tanpa berteriak dan bahkan mungkin mereka tidak mengetahui bagaimana konsep program pembangunan berkelanjutan yang saat ini gencar digalakkan seluruh negara di dunia, mereka justru telah melakukannya dan menyebarkan semangat untuk peduli pada lingkungan hidup. Gerakan tersebut juga mengajarkan penerapan etika bisnis secara nyata. Mereka menunjukkan bahwa bisnis atau usaha di tengah industrialisasi yang didominasi keinginan menumpuk keuntungan namun masih memiliki dan memegang teguh etika terhadap lingkungan hidup.

\section{Relasi Gender dalam Gerakan Peduli Lingkungan}

Gerakan sosial baru berasumsi bahwa masyarakat sipil tengah meluruh, ruang sosialnya mengalami penyiutan dan aspek masyarakat sipil sedang digerogoti oleh kemampuan kontrol negara dan korporasi.Pada konteks ini perjuangan perempuan di kampung Laweyan dan Kauman Surakarta yang berkreasi batik tulis dengan pewarna alami bergerak melintasi wilayah kerja rumah tangga, dari industri sentra batik menyerukan sebuah kondisi adil dan bermartabat bagi makhluk manusia yang kreatif dan berseiring dengan alam.

Gerakan sosial baru bukanlah perjuangan kelas dan bukan cerminan sebuah gerakan kelas seperti paradigma Marxis.Wilayah perjuangan gerakan sosial baru bukanlah ekonomi politik sebuah bangsa melainkan keberagaman mendasar manusia tanpa memandang rasionalitas dan keberagaman sistem ekonomi politik.Perempuan sebagai aktor dalam gerakan sosial baru berjuang untuk meraih otonomi, pluralitas dan keberadaan tanpa menolak prinsip-prinsip egalitarian formal dari demokrasi dan mempertimbangkan keberadaan formal negara dan ekonomi pasar (Singh, 2001).

Gerakan-gerakan sosial semacam gerakan lingkungan hidup yang dilakukan oleh perempuan di kampung Laweyan dan Kauman Surakarta melalui kreasi batik tulis dengan pewarna alami membantu memperluas gagasan-gagasan baru mengenai relasi-relasi gender dan membuka ruang budaya bagi laki-laki, peluang perempuan untuk mempraktekkan gagasangagasannya sehingga menjadi masyarakat egaliter. Perempuan merupakan mayoritas dalam gerakan, baik sebagai anggota maupun pimpinan dan mereka telah menekan laki-laki untuk menghadapi masalah-masalah seksisme. Sebagai hasil pengaruh perempuan dan kelompok-kelompok lainnya, gerakan sosial perempuan Indonesia dalam melestarikan lingkungan hidup melalui kreasinya 
yang terwujud dalam batik tulis dengan pewarna alami menjadi agenda progresif yang luas, yang dapat mengkaitkan masalah lingkungan dengan ras, gender, masalah-masalah lain yang berhubungan dengan keadilan sosial.

Perubahan dalam relasi-relasi keluarga dan gender juga tampak dalam gerakan-gerakan lingkungan hidup baik di kampung Laweyan dan Kauman Surakarta yang didominasi aktivis-aktivis kelas pekerja yang tidak perlu menggunakan feminisme. Kontribusi penting dari gerakan-gerakan ini adalah adanya visi menyangkut potensi-potensi kemanusiaan yang dapat diperluas ke arah relasi-relasi gender. Walaupun perempuan-perempuan yang berpartisipasi dalam gerakan sosial ini masih memegang budaya patriarkhis (Jawa) bahwa lakilaki dan perempuan terpisah, mereka sebenarnya juga memiliki visi tentang tipe komunitas dimana laki-laki dan perempuan bertindak selaku warga negara yang bermoral dan bertanggungjawab.

Di dalam pergerakan-pergerakan perempuan juga mengalami diskriminasi, pada awalnya belum memiliki bahasa atau teori yang memadai untuk menyuarakan keluhan-keluhannya. Namun, ketika berdiskusi diantara mereka mulai menggunakan retorika pergerakan-pergerakan untuk memahami penindasan terhadap diri mereka sendiri. Dalam hal pekerjaan di industri batik, para perempuan mendapatkan pengalaman-pengalaman mengenai relasi-relasi gender yang berubah dalam konteks masyarakat yang lebih luas, seperti jaringan-jaringan perempuan yang terpelajar (akademisi) dalam mencari sarana untuk mengungkapkan kemampuan-kemampuan mereka ke dalam angkatan kerja.

Mungkin yang paling penting adalah pengalaman gerakan sosial telah memberi rasa hormat dan kepercayaan diri yang baru pada perempuan, yang merupakan akibat dari kemampuan mereka untuk bertindak di depan publik (Plummer, 2010). Gerakan-gerakan sosial perempuan dalam melestarikan lingkungan hidup melalui kreasi batik tulis dengan pewarna alami masih menemui kesulitan-kesulitan besar karena mereka harus menghadapi tindakan politik individualistis, budaya-budaya korporasi serta industri-industri yang tidak responsif gender. Namun demikian gerakan-gerakan sosial tetap penting untuk merubah tatanan sosial ekonomi politik yang tidak pro-gender dan tidak peduli terhadap alam. Gerakan sosial baru penting untuk mendesakkan isu-isu lokal yang kurang mendapat kurang perhatian seperti isu batik cap dan printing yang meminggirkan perempuan dan lingkungan hidup. 


\section{Simpulan}

Usaha perempuan untuk mengatasi masalah pencemaran lingkungan hidup akibat dari limbah industri batik cap dan printing di Surakarta adalah melakukan gerakan sosial untuk melestarikan lingkungan hidup melalui kreasi batik tulis dengan pewarna alami. Semangat berbagi dalam pandangan ekofeminisme ini dapat diwujudkan untuk membawa isu lingkungan hidup di tengah industrialisasi yang berkembang. Gerakan sosial ini juga memperluas gagasan mengenai relasi gender dan membuka ruang budaya bagi laki-laki dan perempuan, sehingga masyarakat menjadi egaliter. 
Representasi Semangat Berbagi Ekofeminisme ...

\section{DAFTAR PUSTAKA}

Arivia, G, 2002,“Ekofeminisme: Lingkungan Hidup Berurusan Dengan Perempuan", dalam Jurnal Perempuan, Nomor 21, 111-122.

Asikin,S., 2008, Ungkapan Batik di Semarang. Semarang: Citra Prima Nusantara

Bryman, A, 2011, “Triangulation” dalam Michael S. Lewis-Beck \& Alan Bryman \& Tim Futing Liao.Encyclopedia of Social Science Research Methods.Thousand Oaks: Sage Publications, Inc

Buckingham, S, 2004, "Ecofeminism in the Twenty First Century", dalamThe Geographical Journal, Volume 170, Nomor 2,146-154.

Creswell, J. W., 2006,Qualitative Inquiry and Research Design: Choosing among Five Approaches. Thousand Oaks, CA: Sage Publications, Inc

Daymon, C.dan Holloway, I, 2011, Qualitative Research Methods In Public Relations And Marketing Communications (2nd Edition). London: Routledge.

Demartoto, A, 2012, "Pemberdayaan Perempuan Dalam Pariwisata Berbasis Komunitas (Studi Kasus Tiga Desa Wisata di Jawa Tengah)".(Disertasi). Yogyakarta: Fakultas Ilmu Sosial dan Ilmu Politik Universitas Gadjah Mada.

Denzin, N.K, 1970,The Research Act in Sociology. Chicago: Aldine.

Diekmann, A.dan Preisendorf, P, 2003,“'Green and Green Back, The Behavioral Effects of Environtmental Attitudes in Low-Cost and High-Cost Situation", dalam Rationality and Society, Volume 15, Nomor 4, 441-472.

Doellah, H.S, 2002, Batik: Pengaruh Zaman dan Lingkungan. Surakarta : Danarhadi.

D'Souza, C.dan Peretiatko, R, 2002,“The Nexus Between Industrialization and Environment A Case Studi of Indian", dalam Enterprises. Environtmental Management and Health, Volume 13, Nomor 1, 80-97.

Griggs,D., Mark, S.S., Johan,R., Marcus,C.O., Owen,G., Gisbert,G., Norichika, K., Ian,N., Will,S. dan Priya,S, 2014,"An Integrated Framework for Sustainable Development Goals". Dalam Ecology and Society,Volume 19 Issue 4, 49

Harper, C, 2004, Environment and Society Human Perspective on Environmental Issues. New Jersey: Pearson Education Inc.

Hartini, S., Nurmalasari, S. dan Rinawati, D. I, 2014,“Model Pemilihan Bahan Pewarna Alam Coklat Batik Tulis Solo Dengan Menggunakan Metode Analytical Hierarchy Process (AHP)" dalam J@TI Undip: Jurnal Teknologi Industri Volume IX Nomor 2:77-85

Henslin, J.M, 2006, Essentials of Sociology : A Down To Earth Approach. 7th Edition.Boston: Allyn \& Bacon. 
Hunga, A.I.R, 2004, "Transformasi Kinerja Industri Kecil-Menengah Berbasis Tenaga Kerja Rumahan". Riset Unggulan Terpadu - Menristek-LIPI Salatiga :Pusat Penelitian dan Studi Gender UKSW.

Hunga, A.I.R, 2013,"The Paradox of the Growing Importance of the "PuttingOut" System in the Development of the Batik Industry: A Case Study in the Sragen-Surakarta-Sukoharjo Cluster of Indonesia", dalam The International Journal of Interdisciplinary Organizational Studies Volume. 7 Nomor 2, 1-12

Hutagalung, D., Laclau dan Mouffe, 2006, Tentang Gerakan Sosial. Basis, 01-02, Tahun ke 55. Yogyakarta : Kanisius

Isshiki, Y, 2000,"Eco-Feminism in the 21 Century”, dalam God's Image, Volume 19, Nomor 3: 27.

Lailia, A. N, 2014,“Gerakan Masyarakat Dalam Pelestarian Lingkungan Hidup (Studi Tentang Upaya Menciptakan Kampung Hijau Di Kelurahan Gundih Surabaya)", dalam Jurnal Politik Muda Volume. 3 Nomor 3, 283-302.

Lofland, J, 2007, Protest: Studies of Collective Behavior and Social Movement. New Jersey: Transaction Publisher.

Meliyana, T. S, 2013, “Gerakan Lingkungan Hidup Dalam Menumbuhkan Kesadaran Lingkungan Masyarakat Belitung", Skripsi. Jakarta: Program Studi Pendidikan PKN, Jurusan Ilmu Sosial Politik, Fakultas Ilmu Sosial Universitas Negeri Jakarta.

Meyer, D.S dan Whittier, N, 1994,"Social Movement Spillover”, dalam Social Problem, Volume 41, Nomor 2, 277-298.

Miles, M.B., Huberman, A.M.dan Saldana J, 2014, Qualitative Data Analysis: A Methods Sourcebook. California: Sage Publication Inc.

Moersid, A. F, 2013,"Re-Invensi Batik dan Identitas Indonesia Dalam Arena Pasar Global", dalam Jurnal Ilmiah WIDYA Volume 1, Nomor 2 :121-128

Mokonginta, L. F, 2009, Bumi Bukan Milik Kapitalis. Jakarta : PT. Pustaka Sinar Harapan.

Mitchell, B, 1997,Resource and Environmental Management. Harlow, England: Longman.

Mitchell, B., Setiawan, B. dan Rahmi, D.H, 2003, Pengelolaan Sumberdaya dan Lingkungan. Yogyakarta: Gadjah Mada University Press

Nash, J. Ed, 2005,Social Movements, An Anthropological Reader. Oxford :Blackwell Publishing Ltd.

Nurainun., Heriyana.dan Rasyimah, 2008, "Analisis Industri Batik Di Indonesia”, dalamFokus Ekonomi (FE),Volume 7. Nomor 3, 124 - 135.

Oberschall, A,1993,Social Movement. New Brunswick, NJ:TransactionPublishers 
Representasi Semangat Berbagi Ekofeminisme ...

Plummer, K, 2010, Sociology: The Basic. London: Routledge.

Pringgenies, D., Supriyantini, E. Azizah, R., Hartati, R.Irwani.dan Radjasa, O. K, 2013, "Aplikasi Pewarnaan Bahan Alam Mangrove Untuk Bahan Batik Sebagai Diversifikasi Usaha Di Desa Binaan Kabupaten Semarang'. Majalah Info Edisi XV, Nomor 1

Ramjeawon, T, 2004,“ A Case Study of Cleaner Production Opportunities In Small and Medium Enterprises on Island of Mauritius", dalam Electronic Green Journal, Volume 1, Issue 20: Article 3

Van Roojen, P, 2001, Batik Design. Singapore: The Pepin Press.

Samorna, S, 2013, "Social Movements Against Gold Mining”, dalam Procedia Social and Behavioral Sciences, Volume 88, 299-305.

Schaper, M, 2002,“Small Firms and Environtmental Management Predicator of Green Purchasing in Western Australian Pharmacies", dalam International Small Business Journal, Volume 20, Nomor3, 235-251.

Shifa, V. dan Mies, M, 2005, Ekofeminisme : Perspektif Gerakan Lingkungan dan Perempuan. Alih bahasa: Kelik Ismunanto. Yogyakarta: IRE Press.

Sianipar, C.P.M.,Yudoko G., Adhiutama, A. and Dowaki K, 2013,“Community Empowerment through Appropriate Technology: Sustaining the Sustainable Development", dalam Procedia Environmental Sciences, Volume 17: 1007-1016.

Singh, R, 2001, Social Movement Old and New : A Post-modernist Critique. New Delhi: Sage.

Sridhar,V.K, 2010,"Political Ecology and Social Movements with Reference to Kudremukh Environment Movement", dalam Social Change, Volume 40, Nomor 3: 371-385.

Siswoyo, E, 2006, “Praktik Ramah Lingkungan Industri Kecil di Jakarta: Pemanfaatan Teori Ecological Modernization Untuk Pembinaan Industri Pengolahan Tahu-Tempe Primkopti Swakerta Jakarta Barat Kelurahan Semanan Jakarta Barat", dalam Masyarakat Jurnal Sosiologi, Volume XIII, Nomor 2: 1-26

Soedarmono, 2006, Mbok Mase Pengusaha Batik Laweyan Solo Awal Abad 20. Jakarta : Yayasan Warna Warni Indonesia.

The German-Indonesian Chamber of Industry and Commerce-EKONID, 2011,Clean Batik Initiative, 2010-2012.

Tirta, I, 1996, Batik: A Play of Light and Shades. Jakarta: Gaya Favorit Press.

Tong, R. P, 2013, Feminist Thought: A More Comprehensive Introduction. Fourth Edition.Philadelphia, PA: Westview Press. 


\section{Argyo Demartoto}

Warren, K.J., 1993, A Feminist Philosophical Perspective. In C.J.Adams (ed). Ecofeminism and the sacred (pp.119-132). New York: The Continuum.

Widodo, S., Sunarya, I.K dan Iswahyudi, 2012,"Pewarnaan Bahan Alam Pada Batik Lurik Karya "Batik Natural Sarwidi" Bayat Klaten Jawa Tengah", dalam Jurnal Pend. Seni Kerajinan - S1 (e-Craft), Volume I, Nomor 2: 7-13

Wijaya, M, 2009,“Sistem Produksi dan Keragaman Jaringan Hubungan Produksi Batik di Surakarta”, dalam Jurnal Sosiologi Dilema Volume 21, Nomer 2: 111

Wijaya, M., 2011, Ekonomi Komersial Ganda : Perkembangan Kompleksitas Jaringan Sosial Ekonomi Perbatikan di Surakarta. LPP UNS. Surakarta.

Wulan, T. R, 2007, “Ekofeminisme Transformatif: Alternatif KritisMendekonstruksi Relasi Perempuan dan Lingkungan", dalam Sodality: Jurnal Transdisiplin Sosiologi, Komunikasi, dan Ekologi Manusia, Volume 1, Nomor 1: 105-130 